\title{
Lumbosacral epidural magnesium prolongs ketamine analgesia in conscious sheep ${ }^{1}$
}

\author{
Sulfato de magnésio prolonga a analgesia epidural lombosacral induzida pela quetamina em \\ carneiros
}

\author{
Rafael DeRossi ${ }^{I}$, Cassio Tadeu Dias Pompermeyer ${ }^{\mathrm{II}}$, Amadeu Batista Silva-Neto ${ }^{\mathrm{III}}$, Andrea Lantieri Correa de Barros ${ }^{\mathrm{II}}$, Paulo \\ Henrique de Affonseca Jardim ${ }^{\mathrm{III}}$, Fabrício Oliveira Frazílio ${ }^{\mathrm{IV}}$
}

\begin{abstract}
IPhD, Associate Professor, Department of Veterinary Medicine, Surgery and Anesthesiology, Faculty of Veterinary Medicine and Animal Science, UFMS, Mato Grosso do Sul, Brazil. Tutor. Responsible for conception, design, intellectual and scientific content of the study; anesthesia procedure.

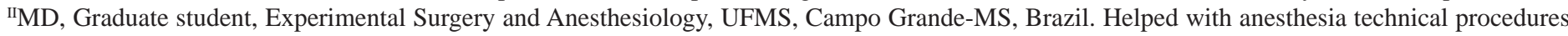
and collection of information.

IIIMD, Fellow Residency, Small Animal Surgery and Anesthesiology, Faculty of Veterinary Medicine, Londrina University (UEL), Parana, Brazil. Helped with anesthesia technical procedures and collection of information.

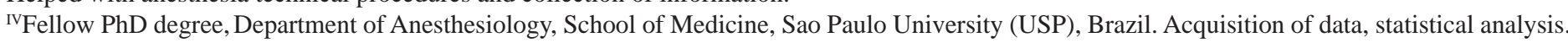

\section{ABSTRACT}

PURPOSE: To determine the analgesic, motor, sedation and systemic effects of lumbosacral epidural magnesium sulphate added to ketamine in the sheep.

METHODS: Six healthy adult male mixed-breed sheep; weighing $43 \pm 5 \mathrm{~kg}$ and aged 20-36 months. Each sheep underwent three treatments, at least 2 weeks apart, via epidural injection: (1) ketamine (KE; $2.5 \mathrm{mg} / \mathrm{kg}$ ), (2) magnesium sulphate (MG; $100 \mathrm{mg}$ ), and (3) KE + MG (KEMG; 2.5 mg/kg + 100 mg, respectively). Epidural injections were administered through the lumbosacral space. Analgesia, motor block, sedation, cardiovascular effects, respiratory rate, skin temperature, and rectal temperature were evaluated before (baseline) and after drug administration as needed.

RESULTS: The duration of analgesia with the lumbosacral epidural KEMG combination was $115 \pm 17$ min (mean \pm SD), that is, more than twice that obtained with KE ( $41 \pm 7 \mathrm{~min})$ or MG ( $29 \pm 5 \mathrm{~min}$ ) alone. KE and KEMG used in this experiment induced severe ataxia. The heart rate and arterial blood pressures changes were no statistical difference in these clinically health sheep.

CONCLUSION: The dose of magnesium sulphate to lumbosacral epidural ketamine in sheep is feasible, and can be used in procedures analgesics in sheep.

Key words: Ketamine. Analgesia, Epidural. Magnesium Sulfate. Sheep.

\section{RESUMO}

OBJETIVO: Determinar os efeitos analgésicos, motores, sedativos e sistêmicos da adição de sulfato de magnésio na analgesia epidural com quetamina em carneiros.

MÉTODOS: Foram utilizados seis carneiros machos sadios, pesando $43 \pm 5 \mathrm{~kg}$, com idade entre 20 a 36 meses. Cada animal recebeu três tratamentos, com duas semanas entre experimentos via administração epidural: (1) quetamina (KE; 2,5 mg/kg), (2) sulfato de magnésio (MG; 100 mg) e (3) KE + MG (KEMG; 2,5 mg/kg + 100 mg, respectivamente). As administrações epidurais foram administradas no espaço lombosacral. Analgesia, bloqueio motor, sedação, efeitos cardiovasculares, frequêencia respiratória, temperatura retal e de pele foram avaliados antes (basal) e depois da administração dos fármacos até o fim da analgesia.

RESULTADOS: A duração da analgesia com o tratamento KEMG foi $115 \pm 17$ min (média \pm DP), duas vezes superior ao obtido com o tratamento KE (41 $\pm 7 \mathrm{~min}$ ) ou tratamento MG ( $29 \pm 5 \mathrm{~min}$ ) isolados. Os tratamentos KE e KEMG induziram bloqueio motor severo. As pressões arteriais e freqüência cardíaca não foram estatisticamente significantes nestes animais.

CONCLUSÃO: A adição de sulfato de magnésio a analgesia epidural com quetamina é viável, e pode ser usado para prolongar os efeitos analgésicos destes bloqueios em carneiros.

Descritores: Quetamina. Analgesia Epidural. Sulfato de Magnésio. Ovinos. 


\section{Introduction}

Epidural anaesthetic blockade is indicated in small ruminants for various surgical procedures in the flanks and part of the thorax to permit orthopaedic surgery of the hind limbs as well as laparotomy. Certain injectable anaesthetics are most extensively used for regional anaesthetic blockade, although they cause adverse effects such as hypotension, respiratory depression, and neurotoxicosis ${ }^{1}$ when administered in excessive dose or accidentally intravascular. Application of a variety of drugs, including local anaesthetics, opioids, adrenergic agonists, and antagonists of $\mathrm{N}$-methyl-D-aspartate (NMDA), in the region of the spinal cord reduces afferent input during surgery and also the metabolic stress response.

Ketamine (KE) is a non-competitive antagonist of the NMDAreceptor and interacts with opioid receptors, monoaminergic receptors, muscarinic receptors, and voltage-sensitive $\mathrm{Ca}^{++}$ channels ${ }^{2}$. Epidurally, $\mathrm{KE}$ is capable of inducing perineal analgesia in humans ${ }^{3}$, horses ${ }^{4}$, and cattle $e^{5,6}$ or subarachnoidly in goats $^{7}$ and sheep ${ }^{8}$. NMDA receptor antagonists prevent central sensitization induced by peripheral nociceptive stimulation and abolish hypersensitization once it is established ${ }^{9}$ by blocking dorsal horn NMDA receptor activation induced by excitatory amino acid transmitters, such as glutamate and aspartate ${ }^{9-11}$. The NMDA receptor is widely distributed throughout all levels of the neuraxis and is intimately associated with physiologic processes relating to acute and chronic pain states ${ }^{12}$.

Magnesium ( $\mathrm{Mg}^{++}$; MG), as $\mathrm{KE}$, is a physiological noncompetitive NMDA receptor antagonist that blocks ion channels in a voltage-dependent fashion ${ }^{13-15}$. Studies with different routes of MG administration (eg, subarachnoid or epidural) showed improved anesthetic and analgesic quality ${ }^{16,17}$. Activation of NMDA receptors leads to calcium and sodium influx into the cell with an efflux of potassium and initiation of central sensitization and wind-up ${ }^{9,11}$. KE, a better known synthetic NMDA antagonist, not only abolishes peripheral afferent noxious stimulation but can also prevent the central sensitization of nociceptors ${ }^{18}$. However, KE and MG inhibit the NMDA system differently ${ }^{14,19}$. MG blocks calcium influx and noncompetitively antagonizes NMDA receptor channels ${ }^{13}$ and KE has a modulatory effect by binding to the NMDA receptors. These effects have prompted the investigation of MG as an adjuvant for postoperative analgesia ${ }^{17,20}$. The combination of drugs with analgesic/anesthetic effects administered by the epidural route seems to present an advantage over the administration of these drugs separately. Drugs can also be synergistic, which accentuates the analgesic/anesthetic effect. Compared with lidocaine administration alone, magnesium sulphate $\left(\mathrm{MgSO}_{4}\right)$ added to lidocaine in caudal epidural administration increases the duration of the analgesic period in horses ${ }^{21}$, cattle ${ }^{22}$, and goats ${ }^{7}$.

The objective of the present study was to determine whether MG added to KE administered by the lumbosacral epidural route in sheep produces analgesia of longer duration and fewer side effects in term of sedation and ataxia.

\section{Methods}

This experiment was approved by the Ethic Commission of Animal Utilization (CEUA) from the Federal University of Mato Grosso do Sul and agrees with the ethical principles of the Brazilian College of Animal Experimentation. Six adult male mixed-breed sheep weighing, $43 \pm 5 \mathrm{~kg}$ (mean $\pm \mathrm{SD}$ ) and aged 20-36 months, were used. Before the experiments began, the sheep underwent biochemical examinations, hemograms, and determinations of anterior diseases, with an evaluation of their general health. Animals were kept at the Faculty of Veterinary Medicine and Animal Science facility during the entire experimental period. The animals were housed in the facility a few weeks before the beginning of the study to become acclimated to the experimental conditions. Three treatments were applied to each animal in a randomly selected way with a minimum of 2 weeks between them. A person who was not involved with the evaluations prepared the drugs and the evaluators were blinded to the drugs and doses administered in each study. Ambient temperature in the laboratory room was around $25^{\circ} \mathrm{C}$ during these experiments.

All sheep were maintained in sternal recumbency with the hind limbs positioned cranially toward thoracic for localization for the lumbosacral epidural space. The lumbosacral region was clipped, shaved, and coated with povidone-iodine solution. Skin overlying the lumbosacral space was infiltrated with $1 \mathrm{~mL}$ of a $2 \%$ solution of lidocaine hydrochloride. The lumbosacral space was identified by the depression between the last lumbar vertebra and first sacral vertebra. A small incision (approximately $1 \mathrm{~cm}$ ) was made in the skin and subcutaneous tissue at this site. An 18-gauge, 12-cm Tuohy epidural needle (Perican, B. Braun, Sao Gonçalo, Brazil) was directed at the epidural space along the median plane. Correct positioning of the needle was confirmed by the hanging drop technique, aspiration of air, and low resistance during injection. Treatments were as follows: 5\% KE (2.5 mg/kg; mean dose $107 \mathrm{mg}$; Ketamin $S^{(+)}$; Cristália Chemical and Pharmaceutical Products, Itapira, Brazil), 10\% MG (100 mg-1 mL) (Isofarma, Pharmaceutical Products, Eusébio, Brazil), and 5\% KE $+1 \mathrm{~mL}$ 10\% MG (KEMG; KE 2.5 mg/kg + 100 mg MG). The volume of 
the drugs was kept constant at $1 \mathrm{~mL} / 7.5 \mathrm{~kg}$ body weight by the use of $0.9 \%$ saline solution (Hipolabor Pharmaceutical, Sabará, Brazil) when necessary. All drugs were injected into the lumbosacral epidural space of each experimental animal.

Heart rate (HR), arterial pressures (systolic [SAP]; diastolic [DAP]; mean [MAP]), respiratory rate (RR), skin temperature (ST), rectal temperature (RT), analgesia, sedation, and ataxia were assessed before drug administration (baseline) and at $5,10,15,30,45,60,75$, and 90 minutes and every 30 minutes thereafter until a score $<3$ was achieved in the pain scoring system outlined below. All animals received a standard painful stimulus with 23-gauge, 2.5-cm needle inserted into the skin and the underlying tissues (deep muscle pricks) at the dorsocaudal ribs, upper and lower flanks, upper hind limbs, and perineal and feet areas (Figure 1).

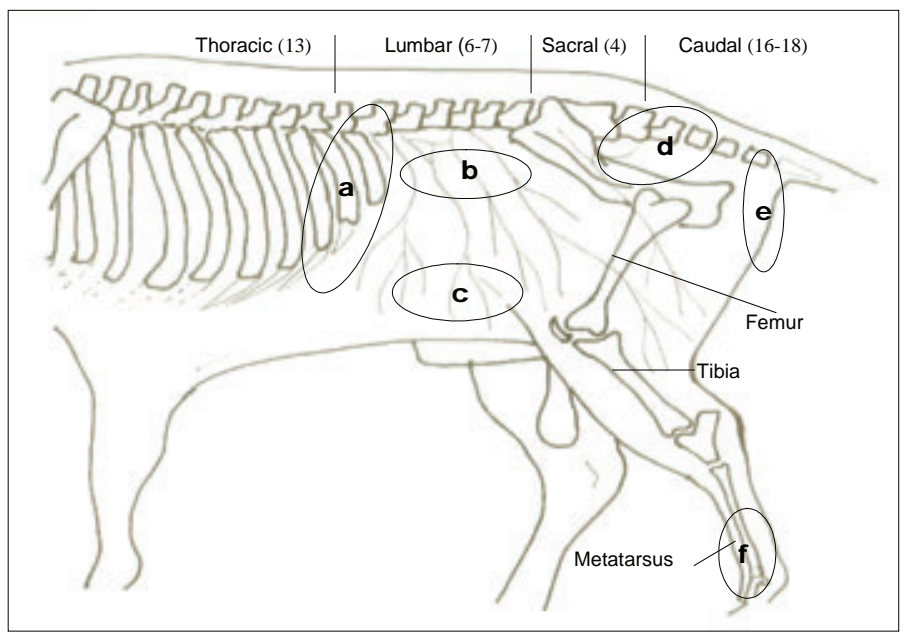

FIGURE 1 - The circle indicates the main areas tested in sheep by standard painful stimulus inserted into the skin and the underlying tissues: (a) dorsocaudal ribs, (b) upper flank, (c) lower flank, (d) upper hind limb, (e) perineum, and (f) feet.

To assess the dermatomal spread of all solutions within the epidural space at different time intervals needle pricks were made at adjacent dermatomic regions, beginning at the tail and proceeding cranially to the thoracic area. ST was used as a complementary test for failure or success of the lumbosacral epidural blocks. The ST was measured with a noncontact infrared thermometer (Minitemp, Raytek, Santa Cruz, CA, USA) at three trichotomized points (upper flank, upper hind limb, and foot regions; Figure 2).

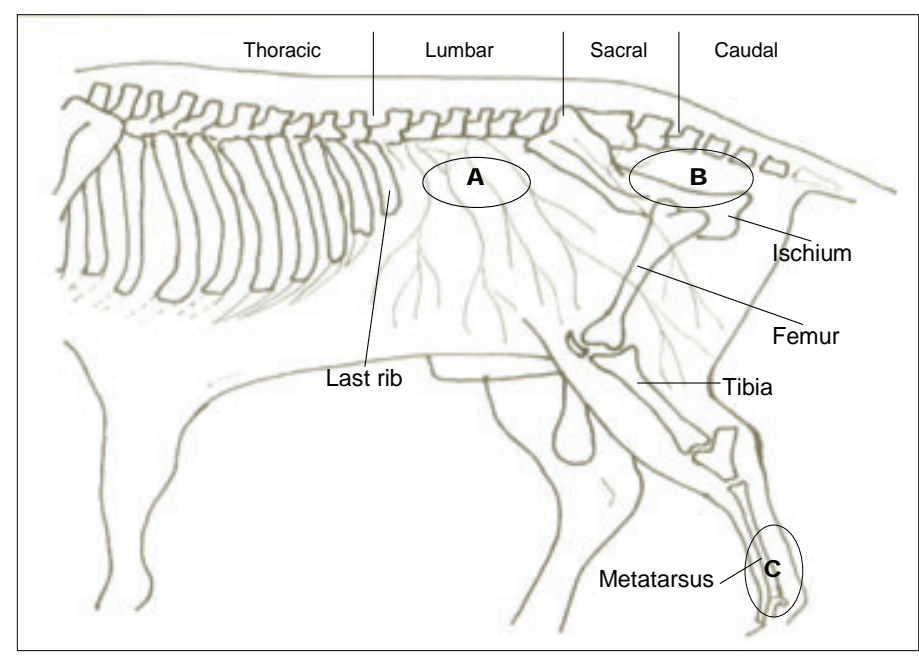

FIGURE 2 - Measurement of ST at three trichotomized points: (a) upper flank, (b) upper hind limb, and (c) foot regions in sheep.

The noxious stimulus made for measure the analgesic score did not made in these regions. The ST was measured for 60 minutes after the blocks; care was taken to measure distant to subcutaneous veins $(20-30 \mathrm{~cm})$. Lack of analgesia (a strong positive response to a noxious stimulus) was ensured before drug administration. Pannicullus response and muscle twitches alone were not considered as painful responses to these stimuli. Analgesic, sedation, and ataxia were evaluated as presented in Table 1 and were assessed before and after each stimulation.

TABLE 1 - Scoring system for analgesic, sedation and ataxia.

\begin{tabular}{|c|c|}
\hline Scores & Definition of scoring \\
\hline \multicolumn{2}{|l|}{ Analgesic } \\
\hline 1 & Strong reaction to painful stimulus with vocalization, tail swishing, or struggle \\
\hline 2 & $\begin{array}{l}\text { Mild analgesia, depressed reaction to a painful stimulus, but restless and turning } \\
\text { toward site of pinprick }\end{array}$ \\
\hline 3 & Moderate analgesia, no response to a painful stimulus but restless \\
\hline 4 & Complete absence of response to a painful stimulus \\
\hline \multicolumn{2}{|l|}{ Sedation } \\
\hline 1 & No sedative effect \\
\hline 2 & Reduced alertness, upper eyelids drooped with no other signs \\
\hline 3 & Sedation with drowsiness and slight drop of the head \\
\hline \multicolumn{2}{|l|}{ Ataxia } \\
\hline 1 & No ataxia \\
\hline 2 & Mild ataxia, difficulty in keeping a standing position \\
\hline 3 & $\begin{array}{l}\text { Moderate ataxia, animal with partial loss of movement of the hind limbs and in lateral } \\
\text { recumbency }\end{array}$ \\
\hline 4 & Severe ataxia, paralysis of the hind limbs and in lateral recumbent \\
\hline
\end{tabular}


Arterial pressure was measured through a cardiac monitor EMAI-RX-300A (Transmai, Hospitalares Medical Equipment, Sao Paulo, Brazil) by using an oscillometric non-invasive device, with the cuff attached to the proximal third of the radius to measure the pressure in the brachial artery. The HR was measured as beats/ min and RR as number of chest movements per minute; RT was measured with a digital thermometer.

All data were analyzed using a general linear model with the SAS software package (SAS Institute Inc, Cary, NC, USA). Data were grouped and summarized as mean \pm standard deviation (SD). A randomized block design was used for each drug, with time as treatment and each of the six animals as a block. For the dependent variables SAP, DAP, MAP, HR, RR, ST, and RT, analysis of variance (ANOVA) differed from baseline (time 0). For anesthesia, sedation, and ataxia-dependent variables, the nonparametric Friedman test was used, followed by multiple data comparison. The Dunnett rank test was also applied, with time 0 being considered as baseline. In each analysis, differences were considered significant when $\mathrm{p}<0.05$.

\section{Results}

Lumbosacral epidural analgesia was produced in all sheep after administration of KE, MG, and KEMG. Time to onset of complete analgesia (grade 3 and 4 ) was significantly prolonged $(P<0.05)$ after MG treatment $(17 \pm 5 \mathrm{~min})$ in comparison with $\mathrm{KE}(5 \pm 3 \mathrm{~min})$ or KEMG treatments $(7 \pm 4 \mathrm{~min})$. The extent of analgesia obtained with the KEMG treatment was similar to that obtained with $\mathrm{KE}$ treatment, extending to dermatomic region T12-13. The KEMG combination produced a longer duration of analgesia (115 $\pm 17 \mathrm{~min}$ ) than the KE treatment (41 $\pm 7 \mathrm{~min})$ in the regions of the dorsocaudal ribs, upper and lower flanks, upper hind limbs, and perineal and feet areas. The MG treatment had a less analgesia (29 \pm 5 min; grades 2 and 3) and a lower blocked area, covering only the upper flank and upper hind limbs (Figure 3).

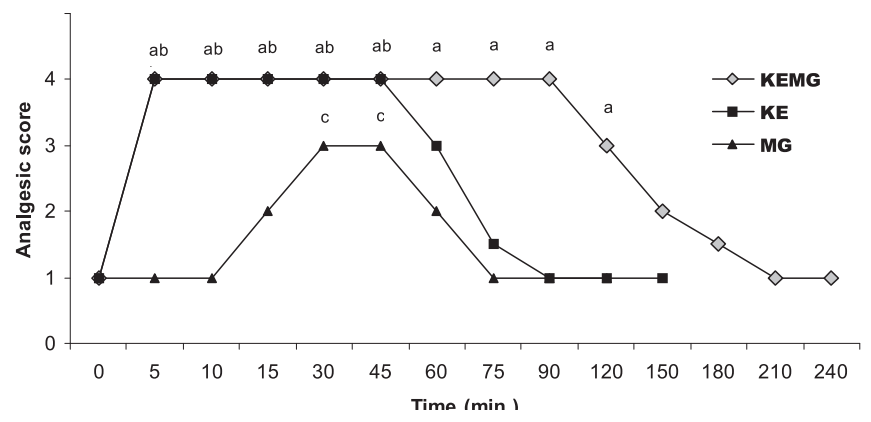

FIGURE 3 - Median analgesic score in response to a standard noxious stimulus at dorsocaudal ribs, upper and lower flanks, upper hind limbs, and perineal and feet areas after lumbosacral epidural administration of $\mathrm{KE}, \mathrm{MG}$, or KEMG in six sheep. The values for KEMG (a), KE (b), and MG (c) differed significantly $(\mathrm{p}<0.05)$ from the respective baseline (time 0) values.

Temperature changed on the skin areas of the upper flank, upper hind limb, and foot regions in all sheep. The time until detectable rise of ST $\left(>1^{\circ} \mathrm{C}\right)$ after the lumbosacral epidural in these areas was $5-10$ minutes $(P>0.05)$ for the KE, MG, or KEMG treatments (Table 2).

TABLE 2 - Skin temperature of six sheep after lumbosacral epidural administration of ketamine (KE, $2.5 \mathrm{mg} / \mathrm{kg})$, magnesium sulphate (MG, $100 \mathrm{mg}$ ) or ketamine plus magnesium sulphate (KEMG, $2.5 \mathrm{mg} / \mathrm{kg}$ ketamine $+100 \mathrm{mg}$ magnesium sulphate) (mean \pm $\mathrm{SD})$.

\section{Times (minutes)}

\begin{tabular}{cccccccc}
\cline { 3 - 7 } Treatments & Anatomical site & Basal & $\mathbf{5}$ & $\mathbf{1 0}$ & $\mathbf{1 5}$ & $\mathbf{3 0}$ & $\mathbf{6 0}$ \\
\hline \multirow{2}{*}{ KE } & Upper flank & $36.0 \pm 0.5$ & $37.4 \pm 0.7$ & $37.4 \pm 0.3^{*}$ & $37.8 \pm 0.4^{*}$ & $38.0 \pm 0.7^{*}$ & $37.3 \pm 1.4$ \\
& Upper hind limb & $36.4 \pm 0.8$ & $37.3 \pm 0.2^{*}$ & $37.3 \pm 0.5^{*}$ & $37.8 \pm 0.6^{*}$ & $37.6 \pm 1.6$ & $37.5 \pm 0.8$ \\
& Feet & $35.1 \pm 0.7$ & $36.1 \pm 0.6$ & $36.6 \pm 0.4^{*}$ & $36.5 \pm 0.2^{*}$ & $36.5 \pm 0.3^{*}$ & $36.2 \pm 0.9$ \\
\multirow{2}{*}{ MG } & Upper flank & $36.8 \pm 0.5$ & $37.5 \pm 0.3$ & $37.9 \pm 0.3^{*}$ & $37.8 \pm 0.4^{*}$ & $37.5 \pm 0.8$ & $36.8 \pm 0.7$ \\
& Upper hind limb & $36.8 \pm 0.5$ & $37.3 \pm 0.7$ & $37.6 \pm 0.4^{*}$ & $37.5 \pm 0.2^{*}$ & $37.4 \pm 0.7$ & $36.6 \pm 0.6$ \\
& Feet & $34.6 \pm 0.8$ & $35.5 \pm 1.3$ & $36.2 \pm 0.6^{*}$ & $35.9 \pm 0.3^{*}$ & $35.8 \pm 0.9$ & $34.8 \pm 0.7$ \\
\multirow{2}{*}{ KEMG } & Upper flank & $35.3 \pm 0.7$ & $36.1 \pm 0.3^{*}$ & $36.8 \pm 0.5^{*}$ & $37.2 \pm 0.5^{*}$ & $37.0 \pm 0.6$ & $36.8 \pm 0.4$ \\
& Upper hind limb & $36.3 \pm 0.7$ & $37.3 \pm 0.4^{*}$ & $37.6 \pm 0.4^{*}$ & $37.0 \pm 1.0$ & $36.7 \pm 1.6$ & $36.8 \pm 1.3$ \\
& Feet & $33.5 \pm 1.4$ & $36.0 \pm 0.7^{*}$ & $35.8 \pm 0.8^{*}$ & $36.3 \pm 1.0^{*}$ & $36.0 \pm 1.0^{*}$ & $36.2 \pm 1.0$ \\
\hline
\end{tabular}

${ }^{*} \mathrm{p}<0.05$ compared to basal value. 
The ataxic effect was more prolonged $P<0.05$ ) with the KEMG treatment (grade 3; $42 \pm 18 \mathrm{~min}$ ) than with the $\mathrm{KE}$ treatment (grade 4; $26 \pm 7 \mathrm{~min}$ ); however, MG treatment had no effect on the motor system in any of the sheep (Figure 4).

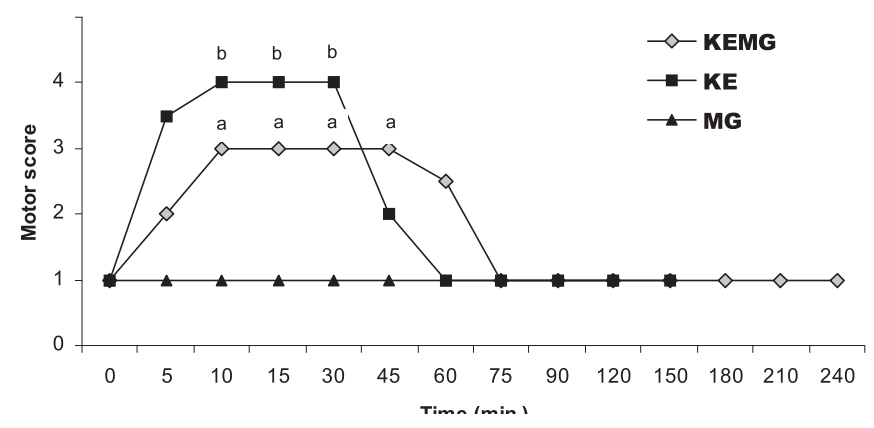

FIGURE 4 - Median score for the ataxic effects of lumbosacral epidural administration of the KE, MG, or KEMG in sheep. The values for KEMG (a), KE (b), or MG (c) differed significantly $(\mathrm{p}<0.05)$ from the respective baseline (time 0 ) values.

Only the KE treatment showed a mild sedative effect (grade 2). HR, RR, SAP, DAP; MAP, and RT did not differ significantly from baseline after lumbosacral epidural administration of KE, MG, or KEMG.

\section{Discussion}

In this study, we demonstrated that the addition of epidural MG, a non-competitive NMDA antagonist, to KE prolongs epidural analgesia in conscious sheep. The median duration of analgesia when $100 \mathrm{mg}$ epidural MG was added to 2.5 $\mathrm{mg} / \mathrm{kg}$ KE was prolonged to 115 min compared with $30 \mathrm{~min}$ and 45 min when MG or KE was used alone, respectively. The analgesia produced by the MG epidural was less intense and had a shorter duration of action. The dose of MG added to the KE epidural was based on data from cattle, horse, and sheep models ${ }^{21-23}$. In these studies, $1 \mathrm{~mL}$ 10\% MG was added to lidocaine, a local anesthetic, aiming to prolong the analgesic effect. But none of these studies examined the administration of MG alone by the epidural route. Noxious stimulation leads to the release of glutamate and aspartate neurotransmitters, which bind to various subclasses of excitatory amino acid receptors, including the NMDA receptor ${ }^{20}$. The $\mathrm{Mg}^{2+}$ ion blocks NMDA receptor-associated channels in a voltagedependent manner ${ }^{14,15}$. NMDA receptor channels are ligandgated ion channels that generate slow excitatory postsynaptic currents at glutamatergic synapses ${ }^{16,24}$. NMDA receptor signalling may be important in determining the duration and intensity of postoperative pain ${ }^{9}$. One report indicated that intrathecal MG enhances opioid analgesia in an acute incisional mode ${ }^{25}$. Both drugs used in this study, KE and MG, block NMDA channels in a voltage-dependent way and reduce NMDA-induced currents ${ }^{12,14,15}$. Another study demonstrated that administration of epidural MG in humans reduced postoperative fentanyl consumption without any side effects ${ }^{17}$. The combination of a non-competitive NMDA antagonist MG with fentanyl, an opioid, and intrathecally administered, prolongs the duration of spinal analgesia in humans ${ }^{20}$. A limitation to the parenteral application of MG for modulation of antinociception via NMDA channel antagonism is insufficient blood-brain barrier penetration to achieve effective cerebrospinal fluid concentrations ${ }^{26}$. MG combined with lidocaine, epidurally administered, induces a longer duration of analgesia than lidocaine alone in cattle or horses ${ }^{21,22}$. In the current study, epidural injection of MG alone induced a short duration of analgesia with a more delayed onset of sensory blockade.

Epidural or subarachnoid injection of KE for perineal or flank analgesia in horses ${ }^{4}$, cattle ${ }^{5,6}$ and goats ${ }^{7,27}$ has been reported previously. Systemically, KE increases arterial blood pressure and stimulates sympathetic activity. This stimulation of the sympathetic system increased the ST in the three treatments in this study. Epidural local anaesthetics induce a local vasodilatation and increase local blood by sympathetic block ${ }^{28}$ with a consequent increase in ST in the blockade regions. Also MG decreases baseline tension in vascular smooth muscle and attenuates the vasoconstrictor response to vasopressor agents ${ }^{29,30}$. As a calcium channel blocker, magnesium sulphate causes a dosedependent negative inotropic effect and peripheral vasodilation ${ }^{31}$. Subarachnoid KE combined with lidocaine provides duration three times as long as that observed after administration of KE alone in goats ${ }^{7}$. In the study reported here, KE combined with MG administered to sheep by the epidural route induced a rapid onset with longer duration of the analgesic effect. Epidural injection of $\mathrm{KE}$ alone in sheep or horses induces a rapid onset but short duration of the analgesic effect ${ }^{4,8}$. These results are similar those obtained in our study with the KE treatment. Onset and duration of analgesia induced by drugs administered via epidural injection will depend on their ability to spread through the meningeal tissue ${ }^{32}$.

In our study, the sheep receiving KEMG and KE treatments presented with ataxia and weakness of the hind limbs. However, ataxia did not occur after epidural administration of MG alone. Doses of epidural MG used in the present study are within the range used in the previous studies with no side effects detected. Several studies showed that intrathecally administered MG has a good safety profile in animals ${ }^{33,34}$. MG infused via the intrathecal route in rats was safe and induced the same histologic changes as did injected lidocaine or physiologic saline ${ }^{33}$. In a study of spinal 
cord ischemia in a canine model, none of the dogs that received intrathecal MG had neurologic injury or histopathologic changes ${ }^{34}$. Another study described an inadvertent intrathecal injection of $1000 \mathrm{mg}$ MG that produced a transient motor block followed by a complete resolution within $90 \mathrm{~min}$ and no neurologic deficit at long-term follow-up ${ }^{35}$. Subarachnoid or epidural injection of KE with similar doses used in this study caused severe block of the motor fibres in horses ${ }^{4}$, goats ${ }^{7}$, and sheep $^{8}$. The ataxic effects observed in our study occurred with both treatments containing KE. Even though the investigation of neural injury was not the purpose of our study, none of the sheep had signs of neurologic disorders.

Epidural anesthesia induces a vasodilatation in the blockade areas. Vasoconstriction develops in areas of the body above the blockade area to minimize the cardiovascular changes resulting from vasodilatation below the level of anesthesia. Low-pressure baroreceptors located in the pulmonary vessels, right atrium, and left atrium and carotid baroreceptors mediate this compensatory increase in vascular tone above the level of sympathetic denervation ${ }^{36}$. Intravenous infusion of $\mathrm{MgSO}_{4}$ slightly decreases arterial blood pressure during epidural lidocaine anesthesia in ewes ${ }^{37}$. In our study, we did not observe any significant changes in cardiovascular variables in sheep after epidural administration of KE, MG, or KEMG at the doses used. Our results are similar to other studies in humans that used intrathecal and epidural $\mathrm{MgSO}_{4}$ (50 mg) administration in combination with fentanyl or bupivacaine ${ }^{16,17,20}$. Finally, none of the sheep demonstrated adverse reactions to epidural MG at any time points assessed. These findings encourage the epidural use of MG in sheep. With its low cost and simple changes in clinical veterinary anaesthesiology practice, MG could do much to decrease pain or stress in the postoperative period.

\section{Conclusion}

The combination of ketamine (2.5 mg/kg) and ) magnesium sulphate (100 mg) administered epidurally in sheep resulted in an increase onset time of analgesia at $7 \pm 4 \mathrm{~min}$ and lengthen analgesia (115 $\pm 17 \mathrm{~min}$ ) of the dorsocaudal ribs, upper and lower flanks, upper hind limbs, and perineal and feet areas compared to KE or MG alone.

\section{References}

1. Blake DW. The general versus regional anaesthesia debate: time to re-examine the goals. Aust N Z J Surg. 1995;65(1):51-6.

2. Hirota K, Lambert DG. Ketamine: its mechanism(s) of action and unusual clinical uses. Br J Anaesth. 1996;77(4):441-4.

3. Bion JF. Intrathecal ketamine for war surgery: a preliminary study under field conditions. Anaesthesia. 1984;39(10):1023-8.

4. Gómez de Segura IA, DeRossi R, Santos M, SanRoman JL, Tendillo FJ. Epidural injection of ketamine for perineal analgesia in the horse. Vet Surg. 1998;27(4):384-91.

5. Lee I, Yoshiuchi T, Yamagishi N, Oboshi K, Ayukawa Y, Sasaki N, Yamada H. Analgesic effect of caudal epidural ketamine in cattle. J Vet Sci. 2003;4(3):261-4.

6. Marsico F, Nascimento PRL, de Paula AC, Nascimento AC Jr, Tendillo FJ, Criado A, Gómez de Segura IA. Epidural injection of ketamine for caudal analgesia in the cow. J Vet Anaesth. 1999;26(1):27-31.

7. DeRossi R, Junqueira AL, Lopes RA, Beretta MP. Use of ketamine or lidocaine or in combination for subarachnoid analgesia in goats. Small Rumin Res. 2005;59(1):95-101.

8. DeRossi R, Carneiro RPB, Ossuna MR, Zanenga NF, Alves OD, Jorge TP, Costa-e-Silva EV, Vasconcelos J. Sub-arachnoid ketamine administration combined with or without misoprostol/oxytocin to facilitate cervical dilation in ewes: A case study. Small Rumin Res. 2009;83(1):74-8.

9. Woolf CJ, Thompson SW. The induction and maintenance of central sensitization is dependent on N-methyl-D-aspartic acid receptor activation; implications for the treatment of post-injury pain hypersensitivity states. Pain. 1991;44(3):293-9.

10. Pockett S. Spinal cord synaptic plasticity and chronic pain. Anesth Analg. 1995;80(1):173-9.

11. Woolf CJ, Chong MS. Preemptive analgesia-treating post-operative pain by preventing the establishment of central sensitization. Anesth Analg. 1993;77(2):362-79.

12. Sukiennik AW, Kream RM. N-methyl-D-aspartate receptors and pain. Curr Opin Anaesthesiol. 1995;8(5):445-9.

13. Fawcet WJ, Haxby EJ, Male DA. Magnesium: physiology and pharmacology. Br J Anaesth. 1999;83(2):302-20.

14. Mayer ML, Westbrook GL, Guthrie PB. Voltage-dependent block by $\mathrm{Mg}^{2+}$ of NMDA responses in spinal cord neurons. Nature. 1984;309(5965):261-3.

15. Nowak L, Bregeslovski P, Ascher P, Herbert A, Prochiantz A. Magnesium gates glutamate-activated channels in mouse central neurons. Nature. 1984;307(5950):462-5.

16. Arcioni R, Palmisani S, Tigano S, Santorsola C, Sauli S, Romano S, Mercieri M, Masciangelo R, De Biasi R A, Pinto G. Combined intrathecal and epidural magnesium sulfate supplementation of spinal anesthesia to reduce postoperative analgesic requirements. Acta Anaesth Scand. 2007;51(4):482-9.

17. Bilir A, Gulec S, Erkan A, Ozcelik A. Epidural magnesium reduces postoperative analgesic requirements. Br J Anaesth. 2007;98(4):51923.

18. Chi YY, Liu K, Liu YC, Chang HC, Wong CS. Adding ketamine in a multimodel patient-controlled epidural regimen reduces postoperative pain and analgesic consumption. Anesth Analg. 1998;86(6):1245-9.

19. Westbrook GL, Mayer ML, Vyklicky L Jr. Sites of antagonist action on N-methyl-D-aspartate acid receptors studied using fluctuation analysis and a rapid perfusion technique. J Neurophysiol. 1988;60(2):645-63.

20. Buvanendram A, McCarthy RJ, Kroin JS, Leong W, Perry P, Tuman KJ. Intrathecal magnesium prolongs fentanyl analgesia: a prospective, randomized, controlled trial. Anesth Analg. 2002;95(3):661-6.

21. Sadegh AB, Shafiei Z. Comparison of caudal epidural anesthesia with lidocaine-distilled water and lidocaine- $\mathrm{MgSO}_{4}$ mixture in horses. J Equine Vet Sci. 2008;28(6):341-4.

22. Dehghani SN, Bigham AS. Comparison of caudal epidural anesthesia by use of lidocaine versus a lidocaine-magnesium sulfate 
combination in cattle. Am J Vet Res. 2009;70(2):194-7.

23. Bigham AS, Shafiei Z. Comparison of caudal epidural anaesthesia with lidocaine-distilled water and lidocaine magnesium sulfate combination in sheep. Bulg J Vet Med. 2008;11(3):125-30.

24. Jeong SM, Hahm KD, Shin JW, Leem JG, Lee C, Han SM. Changes in magnesium concentration in the serum and cerebrospinal fluid of neuropathic rats. Acta Anaesth Scand. 2006;50(2):211-6.

25. Kroin JS, McCarthy RJ, Von Roenn N, Schwab B, Tuman KJ, Ivankovich $\mathrm{AD}$. Magnesium sulfate potentiates morphine antinociception at the spinal level. Anesth Analg. 2000;90(4):913-7.

26. Thuranu GR, Kemp DB, Jarvis A. Cerebrospinal fluid levels of magnesium in patients with preeclampsia after treatment with intravenous magnesium sulfate: a preliminary report. Am J Obstet Gynecol. 1987;157(6):1435-8.

27. DeRossi R, Junqueira AL, Beretta MP. Analgesic and systemic effects of ketamine, xylazine, and lidocaine after subarachnoid administration in goats. Am J Vet Res. 2003;64(1):51-6.

28. Galvin EM, Niehof S, Verbrugge SJC, Maissan I, Jahn A, Klein J, van Bommel J. Peripheral flow index is a reliable and early indicator of regional block success. Anesth Analg. 2006;103(1):239-43.

29. Altura BM, Altura BT. Magnesium ions and contraction of vascular smooth muscles: relationship to some vascular diseases. Fed Proc. 1981;40(12):2672-9.

30. Lee MI, Todd HM, Bowe A. The effects of magnesium sulfate infusion on blood pressure and vascular responsiveness during pregnancy. Am J Obstet Gynecol. 1984;149(1):705-8.

31. Hwang JY, Na NA, Jeon YT, Ro YJ, Kim CS, Do SH. I.V. infusion of magnesium sulphate during spinal anaesthesia improves postoperative analgesia. Br J Anaesth. 2010;104(1):89-93.

32. Bernards CM, Hill HE. Physical and chemical properties of drug molecules governing their diffusion through the spinal meninges. Anesthesiology. 1992;77(4):750-8.

33. Chaminov M, Cohen ML, Grinspun Y, Herbert M, Reif R, Kaufman I, Bahar M. Neurotoxicity after spinal anaesthesia induced by serial intrathecal injections of magnesium sulphate: an experimental study in a rat model. Anaesthesia. 1997;52(3):223-8.

34. Simpson JL, Eide TR, Schiff GA, Gerald A, Clagnaz JF, Hossain I, Tverskoy A, Koski G. Intrathecal magnesium sulphate protects the spinal cord from ischemic injury during thoracic cross clamping. Anesthesiology. 1994;81(6):1493-9.

35. Lejuste MJ. Inadvertant intrathecal administration of magnesium sulfate. S Afr Med J. 1985;68(6):367-8.

36. Zoller RP, Mark AL, Abboud FM, Schmid PG, Heistad DD. The role of low pressure baroreceptors in reflex vasoconstrictor responses in man. J Clin Invest. 1972;51(11):2967-72.

37. Vincent RD, Chestnut DH, Sipes SL, Weiner CP, DeBruyn CS, Bleuer SA. Magnesium sulfate decreases maternal blood pressure but not uterine blood flow during epidural anesthesia in gravid ewes. Anesthesiology. 1991;74(1):77-82.

\section{Correspondence:}

\section{Rafael DeRossi}

Avenida Fellinto Müller, s/n

Caixa Postal 549

79070-900 Campo Grande - MS Brasil

Tel./Fax: (55 67)3345-3600

rafael.rossi@ufms.br

Received: September 8, 2011

Review: November 10, 2011

Accepted: December 14, 2011

Conflict of interest: none

Financial source: FUNDECT (Foundation of Teaching, Science and Technology Development).

${ }^{1}$ Research performed at the Laboratory of Experimental Anesthesia, Faculty of Veterinary Medicine and Animal Science, Federal University of Mato Grosso do Sul (UFMS), Brazil. 